\title{
Pluralisme dalam Realitas Kehidupan Sistem Administrasi Negara Kesatuan Republik Indonesia
}

\author{
Dimyati Huda \\ Institut Agama Islam Negeri Kediri \\ Jl. Sunan Ampel No.7, Ngronggo, Kec. Kota Kediri, Kota Kediri, Jawa Timur, \\ Indonesia
}

Email: dimyati.huda@gmail.com

\section{Tersedia Online di \\ http://www.jurnal.unublitar.ac.id/ index.php/briliant}

\section{Sejarah Artikel}

Diterima pada Mei 2021

Disetuji pada Mei 2021

Dipublikasikan pada Mei 2021

Hal. 389-397

\section{Kata Kunci:}

Pluralisme, Sistem Administrasi

Negara Kesatuan Republik

Indonesia

\begin{tabular}{l}
\hline DOI: \\
\hline http://dx.doi.org/10.28926/brilian \\
t.v3i4.685
\end{tabular}

\begin{abstract}
Abstrak: Pluralisme Dalam Realitas Kehidupan System Administrasi Negara Kesatuan Republik Indonesia sebagai kajian kemajemukan dan keberagaman dan persamaan hak sebagai warga Negarayang mempunyai tugas untuk selalu menebarkan perdamaian. Hubungan pluralisme dalam system administrasi Negara Kesatuan Republik Indonesia sangat erat sekali karena system administrasi Negara kesatuan Republik Indonesia telah terbagi dalam tiga tingkatan pemerintah yaitu pemerintah pusat, wilayah dan daerah kabupaten ataupun kota yang dalam hal ini bukan berarti Negara dalam Negara tetapi sebuah kewenangan yang diberikan Negara terhadap kedaulatan rakyat. Implikasi pluralisme dalam kerangka Negara Kesatuan Republik Indonesia dengan bentuk demokrasi yang berdasar pada Pancasila dan landasan konstitusional UUD 1945.Indonesia sebagai Negara yang terdiri dari pulaupulau dan keberagaman warganya akan keyakinan agama, etnik, suku bangsa dan budaya, maka perlu sosialisasi pemahaman toleransi umat dan keyakinan warga Negara atas hak dan keyakinannya yang dapat dilakukan oleh unsur masyarakat.
\end{abstract}

\section{PENDAHULUAN}

Secara fisik Indonesia terdiri dari lebih 13.000 pulau yang tersebar dengan kemajemukannya. Beberapa etnis, kepercayaan, budaya dan Agama adalah sebuah realitas yang tidak bisa dipungkiri. Agama Islam, Kristen Protestan, Katolik, Budha, Hinduadalah Agama yang diakui di Indonesia untuk diyaqini oleh para umatnya. Dilihat dari kondisi yang berbeda-beda ini tidak salah jika dikatakan bahwa sebenarnya masyarakat Indonesia menyimpan potensi konflik yang tinggi.

Semua Agama mengajarkan kebenaran dan kebaikan serta melarang kerusakan dan kekerasan untuk hidup berdampingan dalam kebersamaan yang damai. Namun masih banyaknya orang yang sering memahami sempit terhadap kebenaran agama, sehingga potensi konflik sangat tinggi yang muncul di masyarakat dan berakibat bencana yang mengancam system administrasi Negara kesatuan Republik Indonesia.

Pada tahun 1999 kota Ternate terjadi kehancuran tatanan sosial yang berakibat dari konflik sosial dan dilandasi oleh nuansa Agama, para pengungsi kehilangan harta benda sanak saudara dan rumah tempat tinggalnya, bahkan 
munculnya trauma yang berkepanjangan bagi para korban, Di lain tempat pada tahun 2001 tepatnya pada tanggal 18 Februari konflik sosial terjadi juga antara etnik Dayak dan Madura. Kemudian pada tanggal 12 Oktober tahun 2002 peledakan bom di Kuta Bali yang mengakibatkan ratusan sarana publik hancur sebagaimana yang di lansir Marian Bali Post 24 Juli 2004 tidak kurang dari 450 gedung atau bangunan menjadi korban selain meninggalnya 202 orang yang 188 adalah warga Asing sedangkan yang mengalami luka-luka 519 orang akibat bom yang meluluh lantahkan roda perekonomian di Bali. Selain itu pada bulan Juli dan Agustus 2004 telah terjadi konflik di Ambon yang dipicu oleh keyakinan Kristen dan Islam akibat isu yang muncul akan datangnya laskar jihad di kota Ambon yang akan memerangi umat Kristen.

Dari kondisi tersebut di atas perlu adanya pemahaman pluralis agar mampu berinteraksi positif dalam menciptakan kerukunan kebhinekaan.pluralisme bukan kosmopolitanisme Pluralisme bukan relativisme dan bukan sinkretisme. Dengan semangat memfungsikan Agama untuk membuka dialog lintas agama dengan misi kalimatun sawa dan kualitas menyelesaikan segala persoalan bangsa, akan mampu mengarahkan umat mempunyai sikap toleran penuh dengan kearifan guna mewujudkan bangsa yang utuh dan maju di tengah keragamanhidup dewasa berbangsa dan mempunyai pola fikir serta prasangka positif guna mencapai harmonisasi demi keutuhan bangsa dan Negara.

Tradisi mendahulukan rasa memiliki Negara, saling menghormati dan bekerja sama serta saling terbukamampu mengiringi dan mengendalikan global civilization dalam "shooting a moving target". Nasionalisme berlandaskan faham kebangsaan menuju kekeluargaan bangsa dan rasa kemanusiaan, keragaman dan mempunyai komitmen yang independen serta mandiridalam setiap tingkatan pemerintahan yakni pemerintahan pusat, pemerintahan propinsi dan Kabupaten ataupun Kota berdasar system administrasi publik di Negara Kesatuan Republic Indonesia yang semua urusan dibagi habis dalam tiga tingkatan pemerintahan tersebut.

Pemahaman terhadap keyakinan akan kecintaan terhadap budaya, suku, Agama dan keyakinan etnis yang menyimpang, telah membuat perpecahan antara warga Negara yang selama ini terkenal dengan jargon bhineka tunggal ika satu kesatuan dalam menciptakan kondisi perdamaian telah teracuni oleh serangkaian konflik yang dipicu oleh kekerasan dan Agama. Faham pluralis yang keliru dengan memperjuangkan ego. Suku bangsa dan kemarahan pribadi ataupun kelompok akan memicu sebuah konflik dan perpecahan. Untuk itu penulis identifikasikan permasalahannya dalam faham pluralisme yang tepat dalam mencegah konflik demi persatuan dan kesatuan bangsa.

Sistem administrasi Negara Kesatuan Republik Indonesia berdasar atas demokrasi sebagai pilihan dan alat untuk mencapai suatu tujuan, dengan adanya beberapa Undang-undang yang dibuat oleh DPR dan Presiden, bukan berarti adanya system dan wewenang yang lebih tinggi dalam Negri ini, karena tidak ada lembaga yang lebih superior diantara lembaga lain. Bahkan demi kedaulatan rakyat jika terjadi suatu ketidak cocokan Undang-undang dengan UUD 1945, maka rakyat dapat langsung mengajukan tuntutan ke Mahkamah Konstitusi demi tegaknya sebuah kedaulatan rakyat. Terjadinya perubahan dengan ditetapkannya beberapa Undang-undang yang salah satunya UU No. 32 tahun 2004 tentang pemerintah

390 BRILIANT: Jurnal Riset dan Konseptual Volume 6 Nomor 2, Mei 2021 
daerah kiranya bukan memisahkan antara pemerintah pusat atau bentuk Negara dalam Negara tetapi demi sebuah kepentingan bersama dalam menghadapi masalah dan perkembangan pembangunan yang pesat dalam wilayah di Indonesia sehingga menuntut adanya pluralisme dan patriotisme sebagai warga Negara yang dipaparkan dalam hubungan antara pluralisme dan sistem administrasi Negara Kesatuan Republik Indonesia.

Pemahaman pluralis bagi setiap warga Negara yang memiliki kedaulatan rakyat dan penghormatan atas hak asasinya sebagai warga yang partisipatif dalam pengembangan dan kelangsungan bingkai atau kerangka Negara kesatuan Republik Indonesia, kiranya perlu adanya diskripsi yang tepat untuk implikasi pluralis dalam mewujudkan persatuan dan kesatuan dengan dasar Negara Pancasila dan dasar konstitusional UUD 1945, yang tentunya UUD 1945 juga telah mengalami perubahan dalam batang tubuhnya sebagai contoh bahwa sebelum reformasi DPR dan Presiden dipilih secara tidak langsung dengan adanya perubahan maka Presiden, Wakil Presiden dan DPR dipilih secara langsung oleh rakyat. Agama adalah suatu keyakinan, menyamakan suatu keyakinan adalah paksaan yang melanggar hak asasi warga Negara, Pluralis bukan berarti memaksakan keyakinan bersama tetapi lebih dari hal tersebut pluralis dapat dimaknai secara implikasinya atas kebersamaan yang hidup saling menghormati atas hak orang lain dan bersama menciptakan suasana kedamaian serta memusuhi perpecahan sebagai bangsa yang hidup dalam Negara Kesatuan Republik Indonesia.

\section{PEMBAHASAN}

\section{A. Pluralisme dalam Realitas Sosial untuk Mencegah Konflik di Indonesia}

Pluralisme adalah sebuah realitas social dengan bermacam keberagaman yang hidup dalam kebersamaan. Djaelani (1995) menyatakan bahwa negara adalah gabungan dari bagian-bagian yang terdiri atas individu, keluarga, kampung. Individu tidak mungkin hidup dalam kesendirian, karena secara fitrah, manusia membutuhkan teman untuk saling memenuhi kebutuhan hidupnya. Kesatuan tersebut membentuk keluarga dan bila digabungkan keluarga yang satu dengan keluarga yang lain terciptalah sebuah kampung yang membentuk Negara.

Al-Farabi dalam Ahmad (1975) berpendapat tentang Negara sebagai suatu kumpulan masyarakat yang saling memenuhi kebutuhan, manusia adalah homosocious (suka bergaul) yang menjadi dorongan untuk berkumpul dan bermasyarakat saling memenuhi kebutuhan dan merupakan bibit timbulnya suatu Negara. Dengan berkumpulnya antara manusia untuk memenuhi kebutuhan ini perlu adanya pemimpin yang mengatur dan mempunyai wewenang yang kemudian terbentuklah Negara. Sementara itu menurut Ibnu Khaldun setiap orang sangat terbatas dan untuk memenuhi kebutuhan itu perlu bantuan orang lain seperti kebutuhan makan dari mulai menanam sampai mengolahnya. Hubungan antara manusia yang satu dengan manusia yang lain terbentuklah masyarakat sebagai syarat mutlak kelangsungan hidup manusia. Untuk mengatur kelangsungan hidup masyarakat dalam memenuhi kepentingan dan perbedaan kepentingan dibutuhkan pemimpin sebagai penengah (wazi'). Pemimpin tersebut harus dapat dipatuhi demi kepentingan bersama. 
Seirama dengan hal tersebut di atas. Khan (1983) menyampaikan bahwa kesejahteraan umat manusia dapat diwujudkan dengan kerjasama dan saling menolong untuk mencegah kesengsaraan, karena manusia sebagai makhluk social yang diorganisasikan dan harus tunduk pada pemimpin yang ditaati. Selain hal tersebut manusia cenderung dikuasai oleh insting pertahanan hidup dan libido serta memiliki potensi distruktif yang besar sebagaimana pendapat Sigmund Freud dan Conrad Lorenz dalam Eric Fromm (2004).

Berkaitan dengan hal tersebut Komaruddin Hidayat (2001) menyatakan bahwa pergaulan dan interaksi social tidak selalu dapat dijalankan dengan manis, ada kalanya mendatangkan rasa suka, tetapi tidak jarang mendatangkan kejengkelan dan kekecewaan pada tingkat tertentu. Rasa jengkel dan kecewa mudah berubah menjadi marah dan timbulnya marah adalah konskwensi dari kodrat manusia sebagai makhluk sosial. Dari pernyataan itu penulis korelasikan dengan terjadinya konflik yang muncul di Indonesia akibat dari marah dan emosi, marah dapat memutuskan persaudaraan, persamaan dalam system Negara kesatuan Republik Indonesia. Untuk hal tersebut kemarahan dapat dikelola, diatur sehingga daya destruksinya menjadi terkontrol.

Rekonsiliasi sebagai penyelesaian konflik kiranya tidak mudah dijadikan solusi utama dalam penyelesaian persoalan. Hal tersebut dibuktikan dengan tidak mudahnya penyamaan persepsi bagi pelaku konflik yang telah dialami di Ambon Maluku, indikasi belum tercapainya rekonsiliasi adalah belum adanya kesepakatan faktor dominan penyebab konflik di Ambon.

Eksistensi dan martabat bangsa harus melindungi keberagaman dan perbedaan yang ada upaya menjaga persatuan bukan hanya warga yang terikat tetapi pesan teologi Agama apapun selalu mengajarkan menerima perbedaan dalam keberagamaan sebagai cermin kekuasaan Tuhan. Betapa naï dan piciknya jika mengingkari keberagaman dan menolak kebersamaan karena sifat ini akan muncul ketidaknyamanan dalam hidup untuk itu saling menyadari dan menerima perbedaan yang ada adalah lebih indah dalam keberagaman. Pluralisme bukan mengubah bunga mawar menjadi bunga melati dan bunga kamboja menjadi bunga dahlia tetapi bunga - bunga tersebut harus dijaga tetap harum dan hidup dalam pandangan yang menyejukkan.

\section{B. Hubungan Pluralisme dalam Sistem Administrasi Negara Kesatuan Republik Indonesia}

Hoessein (2009) menyampaikan bahwa sejak tahun 1903 pemerintah daerah di Indonesia telah dibagai menjadi enam putaran yang dilihat dari sudut pandang nilai yang hendak diwujudkan. Putaran pertama pada tahun 1909 -1922 adalah wujud menuju nilai efisiensi. Putaran kedua, kurun waktu tahun 1922-1942 menuju nilai efisiensi dan partisipasi. Kurun waktu ini menunjukkan bahwa kondisi pendulum berada di tengah kontinum antara nilai efisiensi dan partisipasi. Putaran ketiga pada masa 1945-1959 menuju demokrasi atau kedaulatan rakyat. Putaran keempat pada masa 1959-1974 menuju stabilitas dan efisiensi pemerintahan dan putaran ke lima berada dalam kurun waktu 1974-1999 menuju efisiensi dan efektifitas pelayanan public dan pembangunan sedangkan putaran keenam terjadi sejak reformasi 1999 yang menekankan partisipasi dan demokrasi menuju keberagaman dalam penyelenggaraan pemerintah daerah.

392 BRILIANT: Jurnal Riset dan Konseptual Volume 6 Nomor 2, Mei 2021 
Perubahan menjadi varian kultur yang lebih heterogen dan pranata social yang lebih beragam untuk itu bekerjanya prinsip pemerintah sebagai bentuk baru dari administrasi public yang banyak ditentukan oleh deposit dan konfigurasi capital social yang tersedia dalam wilayah publik.

Menurut Piotr (2005) kemungkinan perubahan pada:

1. Perubahan komposisi misalnya migrasi dari satu kelompok lain menjadi satu kelompok tertentu, pengurangan jumlah penduduk karena kelaparan, demobilisasi gerakan social, bubarnya suatu kelompok)

2. Perubahan struktur misalnya terciptanya ketimpangan kristalisasi kekuasaan, munculnya ikatan persahabatan, terbentuknya hubungan kompetitif

3. Perubahan fungsi misalnya spesialisasi dan diverensiasi pekerjaan, hancurnya peran ekonomi keluarga diterimanya peran yang diinduktrinasikan oleh sekolah atau universitas)

4. Perubahan batas misalnya penggabungan kelompok atau satu kelompok oleh kelompok lain dan mengendurnya criteria keanggotaan kelompok dan demokratisasi keanggotaan dan penaklukan)

5. Perubahan hubungan antara sub system misalnya penguasaan rezim politik atas organisasi ekonomi, pengendalian keluarga dan keseluruhan kehidupan privasi oleh pemerintah totaliter.

6. Perubahan lingkungan misalnya kerusakan ekologi, gempa bumi, munculnya wabah atau virus HIV dan lenyapnya system bipolar internasional.

Seperti halnya penjelasan di atas bahwa prubahan social dapat terjadi pada tingkat makro seperti system internasional, bangsa dan Negara. Dapat juga terjadi pada tingkat Mezo seperti pada perusahaan, partai politik, gerakan keagamaan dan asosiasi besar atau ditingkat mikro seperti pada keluarga, komunitas kelompok pekerjaan dan lingkungan pertemanan. Perubahan social dapat saling mempengaruhi, dengan adanya krisis ekonomi dan krisis di segala bidang telah mengakibatkan prustasi masyarakat.

Reformasi yang terjadi pada tahun 1998 telah mendorong pemerintah segera menerapkan Undang-undang yang demokratis dan partisipatif dengan ditetapkannya undang-undang No. 22 tahun 1999 tentang pemerintah daerah sebagai pengganti Undang-undang No. 5 tahun 1974. Walaupun dalam perjalanan undang-undang tersebut telah terganti juga dengan No. 32 tahun 2004, tetapi semangat daerah untuk berkreasi dan berinovasi dalam rangka membuat suatu perubahan yang lebih baik berjalan signifikan.

Tiga tingkatan pemerintah dalam system administrasi publik di Negara Kesatuan Rrepublik Indonesia. Yakni penyelenggara administrasi public diberbagai tingkatan baik pemerintah pusat, wilayah maupun Kabupaten/ Kota sebagai perkembangan pemikiran jenis pemerintah sub regional yang strategis untuk mempertahankan Negara kesatuan republic indonesai yang didirikan berdasar pada UUD 1945 sebagai landasan konstitusional dan Pancasila sebadai dasar Negara. Dalam Pembukaan UUD 1945 telah dinyatakan tujuan Negara adalah untuk mensejahterakan masyarakat. Terjadinya konflik tentunya membuat keresahan masyarakat yang berakibat tidak nyaman dan tidak aman dalam melangsungkan kehidupan di Indonesia untuk hal tersebut dengan kewenangan UU No. 32 Tahun 
2004 tentang Pemerintah daerah tentunya langkah terbaik bagi sub regional atau wilayah kabupaten yang tersebuar di kepulauan Indonesia untuk menempatkan masyarakat berpartisipasi aktif dalam pembangunan, mengedepankan kebersamaan dan penyelesaian permasalahan secara berasama dalam kehidupan yang beragam.

\section{Implikasi Pluralisme dalam Kerangka Negara Kesatuan Republik Indonesia}

Paham pluralisme dalam masyarakat sering memunculkan konflik yang berujung pada tidakan kekerasan dan dilakukan oleh kelompok etnik atau agama tertentu, bahwa etnik dan agama hanyalah topeng dari konflik. Ada banyak dugaan bahwa konflik lebih berorientasi pada sumber daya yang ada, baik itu ekonomi, sosial politik ataupun yang lainnya. Sementara etnik dan agama menjadi kendaraan bagi perebutan sumber-sumber tersebut. Tanpa disadari oleh masyarakat terseret dalam konflik itu (Judy Syarifuddin, 2010).

Konflik juga dapat muncul karena adanya desas-desus yakni berita yang menyebar secara cepat dan tidak berlandaskan fakta (kenyataan) desas-desus muncul jika terjadi ketegangan sosial (Horton, Paul B dan Hunt, Chester, 1999).Untuk hal tersebut penekanan terhadap makna yang benar terhadap faham pluralisme yang implikasinya dalam kerangka Negara Kesatuan Republik Indonesia yang mengedepankan demokrasi, bahwa kedaulatan di tangan rakyat.

Kerangka Negara Republik Indonesia tidak terlepas dari faham demokrasi yang telah menjadi pilihan bangsa Indonesia untuk dijadikan alat atau cara mencapai tujuan bersama. Demokrasi adalah pilihan yang terbaik diantara yang buruk. Contoh kekuarangannya adalah sebuah keputusan yang diambil berdasar kuantitas dan bukan kualitas, yang banyak suara dialah yang menang, padahal mayoritas suara belum tentu kebenarannya, untuk hal tersebut demokrasi perlu dikontrol dengan adanya mahkamah konstitusi. Dimana Undang-undang yang dibuat oleh 550 orang legislator dan presiden yang dua-duanya dipilih langsung oleh masyarakat sebagai cermin dari mayoritas kehendak rakyat.

Negara mempunyai kepentingan tersendiri dalam intervensi terhadap kepentinganmasyarakat. Konsep kebaikan umum dengan keharusan moral yang dibebankan kepada Negara untuk menyelenggarakan kesejahteraan masyarakat, membuka kesempatan bagi Negara untuk merumuskan dan dengan inisiatif sendiri memaksakan perubahan besar kepada masyarakat baru yang lebih baik (Jurdi Syarifuddin: 2010).

Pemahaman yang tepat pada faham pluralism sangat diperlukan guna mencapai cara pandang yang komprehensif bagi setiap warga Negara, bahwa pluralisme bukanlah pemaksaan keyakinan terhadap orang lain tetapi menghormati keberagaman, kemajemukan dalam hidup berdampingan dengan kerangka Negara kesatuan Republik Indonesia. Selain itu setiap unsure warga Negara harus mampu membentuk karakter bahwa mencintai bangsa dan tanahair adalah bagian dari kesalehan sosial, serta dapat mencapai budaya sains tehnologi dalam bingkai keindonesiaan. Keberagaman yang diikat dengan semangat kebhinekaan menjadi modal kekayaan bangsa Indonesia, keberanian dan kemandirian bangsa dimulai dari kepercayaan diri yang terus berbenah dari segala bidang, sumber daya manusia Indonesia sebagai aset bangsa yang mampu menyebarkan pola fikir dan membentuk generasi dengan harga diri unggul guna mencapai masyarakat sejahtera.

394 BRILIANT: Jurnal Riset dan Konseptual Volume 6 Nomor 2, Mei 2021 


\section{KESIMPULAN}

Dari pemaparan yang telah penulis uraikan dapat disimpulkan bahwa paham pluralisme jika diberi makna kebersamaan untuk mempertahankan sebuah kelompok, Agama, etnik dan golongan maka perpecahan akan rentan terjadi, namun jika pluralisme dalam artian yang sebenarnya adalah kebersamaan dalam kemajemukan dan keberagaman maka konflik di Indonesia dapat dicegah munculnya karena merasa adanya persamaan hak sebagai warga Negara dan makhluq ciptaan Tuhan yang mempunyai tugas untuk selalu menebarkan perdamaian.

Hubungan pluralisme dalam system administrasi Negara Kesatuan Republik Indonesia sangat erat sekali karena system administrasi Negara kesatuan Republik Indonesia telah terbagi dalam tiga tingkatan pemerintah yaitu pemerintah pusat, wilayah dan daerah kabupaten ataupun kota yang dalam hal ini bukan berarti Negara dalam Negara tetapi sebuah kewenangan yang diberikan Negara terhadap kedaulatan rakyat.

Implikasi pluralisme dalam kerangka Negara Kesatuan Republik Indonesiadengan bentuk demokrasi yang berdasar pada Pancasila dan landasan konstitusional UUD 1945 adalah sebagai pijakan warga Negara Indonesia untuk hidup dalam kemajemukan dan keberagaman demi perdamaian dan persatuan dalam bingkai atau kerangka Negara kesatuan Republik Indonesia.

\section{SARAN}

Dengan melihat Indonesia sebagai Negara yang terdiri dari pulau-pulau dan keberagaman warganya akan keyakinan agama, etnik, suku bangsa dan budaya, maka perlu sosialisasi pemahaman toleransi umat dan keyakinan warga Negara atas hak dan keyakinannya yang dapat dilakukan oleh unsure masyarakat yang mempunyai kepedulian terhadap persamaan hak dan kewajiban sebagai warga Negara.

Pimpinan pemerintah baik pusat, wilayah maupun daerah harus menjadi tauladan sebagai pemimpin yang mampu menyebarkan pemahaman yang tidak terkotak-kotak walaupun keberadaannya tidak terlepas dari proses politik pemilihan secara langsung dari partai politik yang memberangkatkannya, maka dengan semangat kebersamaan dalam perdamaian untuk menciptakan persatuan dan kesatuan bangsa harus diawali dari keberadaan pemimpin tersebut dan menghormati warga Negara untuk partisipatif dalam pembangunan tanpa membedakan warna kulit, etnik, suku dan agama.

\section{DAFTAR RUJUKAN}

Adam B. Seligman. 1998. Between Public and Private: Towards a Sociology of Civil Society dalam Robert W. Hefner (eds), 1998, Democratic Civility : The History and Cross-Cultural Possibility of a Modern Political Ideal. New Brunswick (USA): Transaction Publishers

Ahmad. 1975. Konsep Negara Bermoral Menurut Al-Ghazali. Jakarta: Bulan Bintang 
Anwar. Desy. tt. Kamus Lengkap Bahasa Indonesia. Amelia. Surabaya Bali Post. 24 Juli 2004

Box, Richard C,. 1998. Citizen Governance: Leading American Communities into the $21^{\text {st }}$ Century. London: Sage Publications

Burnes, Bernard. 2004. Managing Change: A Strategic Approach to Organisational Dynamic. England: Pearson Education

Dahl, Robert A. 1998. On Democracy. London: Yale University Press.

Darwin, Muhajir. 2000. Akuntabilitas Pelayanan Publik, makalah disampaikan dalam Seminar Sehari FISIPOL UGM. Yogyakarta.

Djaelani, Abdul Qodir. 1995. Negara Ideal Menurut Konsep Islam. Surabaya: Bina Ilmu

Fromm, Eric. 2004. The Anatomy of Human Destructive (trjh). Yogyakarta: Pustaka Pelajar.

Fukuyama, Francis. 1999. The Great Discription: Human nature and the Reconstitution of Social Order, Free Press Paperback Book. Simon and Schuster. New York.

Hidayat, Komaruddin. 2001. Agama di Tengah Kemelut. Jakarta: Media Cita

Hoessein, Bhenyamin. 2009. Perubahan Model dan Bentuk Pemerintahan Daerah. Jakarta: DIA FISIP UI

Harton, Paul B dan Chester L. Hunt. 1999. Sosiologi Jilid 2 Edisi Keenam.Judul Asli: Sosiology Sixth Edition. Jakarta: Erlangga

Huda, Dimyati, M,. 2009. Pluralisme dalam Beragama. Kediri: STAIN Kediri Press

Jurdi, Syarifuddin. 2010. Sosiologi Islam Masyarakat Modern Teori. Fakta dan Aksi Sosial. Jakarta: Kencana

Khan, Qomaruddin. 1983. Pemikiran Politik Ibnu Taymiyah. Bandung: Pustaka

Kobrak, Peter. 1996. "The Social Responsibilities of A Public Entrepreneur, dalam Administration and Society" 28 (2) August 1996.

Levi, Margaret. 1999. When Good Defenses Make Good Neighbors: A Transaction Cost Approach to Trust and Distrust, Paper originally prepared for presentation at the $2^{\text {nd }}$ Annual Meeting of the International Society for the New Institutional Economic (ISNIE), Paris September, 17-19, 1998 and at the Conference on Social Networks and Social capital, Duke University, October 30 November 1. 1998. Revised at January. 1999. Published by Department of Political Science. University of Washington

Ndraha, Taliziduhu. 1997. Budaya Organisasi. Jakarta: Rineka Cipta

Norton, Alan. 1994. International Handbook of Local and Regional Government: a Comparative Analysis of Advanced Democracies. Cheltenham Edwar Elgar.

Opeskin, D. 1998. The Reform of Intergovernmental Fiscal Relation on The Developing and Emerging Market Economies. Washington, DC: World Bank.

Piotr, Sztompka. 2005. Sosiologi Perubahan Sosial. Jakarta: Prenda Media

Soenarto. 2003. Euforia Reformasi Revolusi Pergulatan Ideologi dalam Kehidupan Berbangsa. Yogyakarta: Pustaka Pelajar.

396 BRILIANT: Jurnal Riset dan Konseptual Volume 6 Nomor 2, Mei 2021 
Stephen, Knack. 2000. "Social Capital and the Quality of Government: Evidence from the U.S. States, World Bank" Paper availabel at http://wwwl.worldbank.org/publicsector/.downloaded at Juni, 10, 2010.

Thoha, Miftah. 2003. Birokrasi dan Politik di Indonesia. Raja Grafindo. Jakarta: Persada

Thomas D. Lynch dan Cynthia E. Lynch. 2000. A Theory of Soul. LousianaState, University Amerika. availabe on http://www.uwf.edu/whitentr/clynch.htm .downloaded at Juni, 15, 2010.

Yates, Douglas. 1982. Bureaucratic Democracy: The Search for Democracy and Efficiency in American Government. Cambridge: Harvard University Press. 